\title{
A PRIMER ON BARTLETT'S \\ CRITIQUE OF IMPURE REASON
}

\begin{abstract}
Steven James Bartlett
KEYWORDS: epistemology, theory of reference, theory of meaning, theory of possibility, self-reference, reflexivity, transcendental argumentation, Steven James Bartlett, Critique of Impure Reason
\end{abstract}

\begin{abstract}
ome books are long and complex. The Critique of Impure Reason is such a book. It is long enough and complex enough so that it may be a service to some readers to offer a primer to introduce and partially summarize the book's objectives and method. Here, the author of Critique of Impure Reason: Horizons of Possibility and Meaning provides such a guide, a vade mecum to accompany a reader should he or she embark on a study of the long and complex work.
\end{abstract}

The author has chosen to issue this paper as a free open access publication under the terms of the Creative Commons Attribution-NonCommercial-NoDerivs license, which allows anyone to distribute this work without changes to its content, provided that both the author and the original URL from which this work was obtained are mentioned, that the contents of this work are not used for commercial purposes or profit, and that this work will not be used without the author's or his executor's permission in derivative works (i.e., you may not alter, transform, or build upon this work without such permission). The full legal statement of this license may be found at

$\underline{\text { http://creativecommons.org/licenses/by-nc-nd/4.0/legalcode }}$

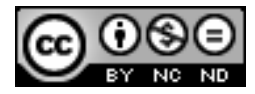

The text in $\S \S 3-11$ and 13 of this paper is licensed under the Creative Commons Attribution-ShareAlike License.

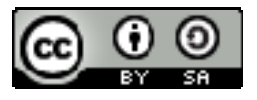

DOI: $10.5281 /$ zenodo. 5789848

URL: https://doi.org/10.5281/zenodo.5789848

(C) Steven James Bartlett 2021 


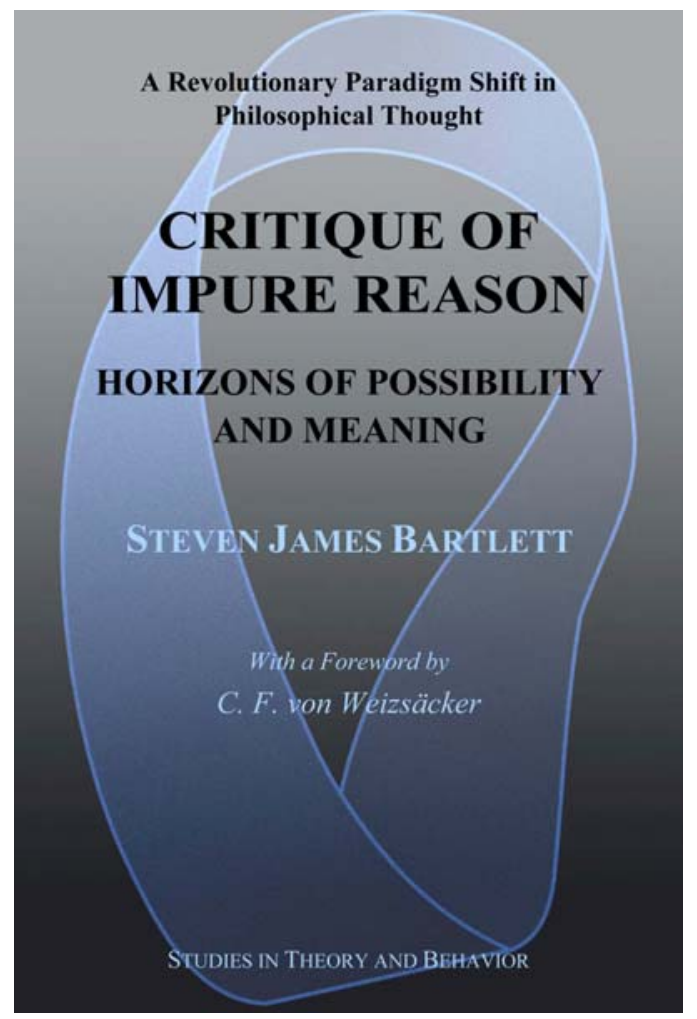

884 pages, 30 chapters, 1 supplement, 2 appendices 412 notes, 628 referenced sources, index

Critique of Pure Reason: Horizons of Possibility and Meaning was published in September, 2020, in the form of a preliminary eBook edition and made freely available through online philosophy archives.

In light of the strong response to the eBook edition, and for readers who may find that reading a nearly 900 -page book on their screens is inconvenient or uncomfortable, in September, 2021, the publisher released a printed edition. It is available from independent and online book dealers, including Amazon and Barnes \& Noble, where it can be ordered under ISBN 978-0-578-88646-6.

Also in September, 2021, a corrected second eBook edition was published and made freely available through online archives, including PhilSci, PhilPapers, HAL, Erasmus University, and others.

Readers are asked to use either the printed edition or the corrected second eBook edition. 


\section{CONTENTS OF THIS PRIMER}

\$1. Conventional boxes and the need to think outside them

§2. Philosophical "what ifs"?

§3. What a "critique of impure reason" means

$\S 4$. Relationship to Immanuel Kant's Critique of Pure Reason and to Kant's notion of a "negative science"

$\S 5$. The structure and contents of the Critique of Impure Reason

§6. How the Critique of Impure Reason demonstrates or proves its claims

§7. The philosophical purpose of the Critique of Impure Reason

§8. Recognition of Bartlett's work in philosophy and commendations of the Critique of Impure Reason

§9. Previously published work by Bartlett leading to the Critique of Impure Reason

§10. External links and resources: Books, monographs, and papers by Steven James Bartlett available online

\$11. Additional online resources

\$12. Postscript: Why this book was published Open Access

§13. Endnotes

\section{§1. Conventional boxes and the need to think outside them}

We do not often pay explicit attention to the frameworks in terms of which we seek to understand the world, and less seldom do we question them. We are often urged to "think outside the box," but to do this effectively, intelligently, and adequately - if we are to free ourselves from their influence-we must gain sufficient distance from our often unselfconscious frames of reference. If we are able to do this, we may recognize the constraints our frames of reference inevitably place on what we can comprehend by their means.

It is safe to say that there are no frames of references which ought to be accepted-at least by philosophers - without a measure of critical, reflective analysis. Without that analysis, we remain subject to in-built assumptions which can determine the scope of our interests, motivations, and abilities to imagine, and we thereby remain subject to our tendencies either to dismiss what we regard as uninteresting, unmotivating, and inconceivable, or we remain simply ignorant of possibilities that would never occur to us.

Perhaps the most invidious and insidious of all of the ways in which our frameworks of reference can box us in and shut us out from what we might otherwise see and understand comes about thanks to the Devil's Quintet whose players are Fashion, Style, 
Restrictive Paradigms, Preferred Beliefs, and Taste. Often these players create their harmonies so well that they blend together in a single line of convention. For philosophers, no less than ordinary mortals, the Devil's Quintet places blinders on any of us who embrace-whether consciously or without explicit reflection-prevailing philosophical fashions, preferred styles of doing philosophy, authorized paradigms for philosophical research, sets of philosophical beliefs we cannot prove but yet invest our energies in defending, and philosophical tastes that lead us to disregard, ignore, or oppose that which does not satisfy our palates.

Much of the history of philosophy can be traced to changes in the tunes played by the members of the Devil's Quintet. This is, of course, no less true of other disciplines whose human contributors are equally human, and many of whom are unable to think outside the boxes in which their preferred frameworks confine them.

The Critique of Impure Reason begins with two chapters that seek to look closely at the psychology of philosophers - for the harmonies played by the Devil's Quintet, at any time during philosophy's long history, are of a special psychological sort that will ring true to the ears of a great many philosophers of that time. As philosophers, we tend to be suspicious, and often critical, of "psychologizing," and yet any philosopher who attempts to push, stretch, or break free from the boundaries of the conventional boxes that mainstream philosophy accepts, prefers, and will defend is a person who will, almost inevitably, run afoul of the conventionally prescribed boundaries of what, at that time, is judged to be philosophically acceptable.

Some of these prescribed boundaries that serve to restrict us to the confines of our preferred philosophical boxes are described in the first two introductory chapters of the Critique of Impure Reason. They point to conventional constraints that often limit and stand in the way of the development and evolution of the discipline, constraints some of which, and of a specialized kind, the Critique of Impure Reason seeks to move beyond.

\section{§2. Philosophical “what ifs”?}

"The only way you will identify your own conceptual blocks is to try activities which are impeded by their existence."

\section{- James L. Adams, Conceptual Blockbusting: A Guide to Better Ideas ${ }^{1}$}

"What ifs" sometimes can help us take note of boxes we might wish to think outside of. Consider the following philosophical "what ifs":

- What if many of the main problems that have occupied philosophers for millennia are not true problems at all, but instead are complex, intricately interwoven errors that involve, so to speak, conceptual sleights of hand: an intertwining of concepts that are not what they seem, but instead embody disguised forms of deception which we have been unable to see?

\footnotetext{
${ }^{1}$ San Francisco: W. H. Freeman, 1974, p. 11.
} 
- What if philosophical fashions, styles, restrictive paradigms, preferred beliefs, and tastes have orchestrated together in such a way as to foster our very human blindness to this unrecognized variety of deception?

- What if a philosopher were to point to such an alleged phenomenon of blindness that prevents us from recognizing this form of conceptual illusion? what response by the philosophical community to his or her pointing would be most predictable?

- What if, through appeal to the very tenets of rationality, reason, and logical consistency that we so widely respect, it can be shown-with the strictness of mathematical proof - that such deception is widespread and that it has led to the development of a vocabulary of philosophical concepts that perpetuate that very form of deception?

- What if, however, a minority of philosophers responds to the appeal of "thinking outside the box" and becomes determined to push, stretch, and perhaps break free from the constraints that have held philosophy back and prevented the discipline from achieving determinate, provable, enduring results that can be built upon in the future?

- What if an individual philosopher is successful in breaking free from those constraints, at least in his or her own thinking? what perspective would such a person come to have as he or she then re-evaluates the main philosophical questions that have remained enduringly unanswered for millennia?

- What if these "what ifs" should actually come about?

- But what if the Devil's Quintet plays so loudly that nothing else can be heard?

The Critique of Impure Reason undertakes a careful, logically rigorous exploration of these "conceptual blockbusting" issues. Its central objective is a critique of reason that is "impure" in certain specific and well-defined ways which have not been identified before. To accomplish this end, the book formulates a pioneering method whose purpose is to make explicit the unavoidable limits of meaning and knowledge. In the process, a wide range of traditional philosophical questions and problems find their often surprising, insightful, and compelling solutions.

\section{§3. What a "critique of impure reason" means}

[In what follows, reference is made to me, the author, in the third person since the text derives from an external source. $\left.{ }^{2}\right]$

${ }^{2}$ Until otherwise indicated, the text in this and subsequent sections is reprinted, with thanks and acknowledgment to Wikipedia, from the Wikipedia article "Critique of Impure Reason" (accessed 
Bartlett explains that by a "critique of impure reason" is meant a critique of the limitative boundaries beyond which concepts and claims lead to "impure reason," undermining the very conditions of their possible meaning. The central thesis of the book is that many major traditional philosophical problems can be solved in a rationally compelling manner once we recognize and rein in the many ways in which we seek to overstep these limiting boundaries. When we try to trespass beyond these boundaries, which the Critique of Impure Reason calls the "horizons" of reference, we employ concepts and make claims that violate the very conditions that must be granted for them to possess any possible meaning. The book's objective is to understand the unavoidable boundaries of the frameworks we use, and to help us to avoid conceptual confusions that come about when attempts are made to transgress beyond what is possible and meaningful.

\section{§4. Relationship to Immanuel Kant's Critique of Pure Reason and to Kant's notion of a "negative science"}

Kant's Critique of Pure Reason, published in two editions, in 1781 and 1787, sought to provide a critique of the "faculty of reason in general," and by doing this it attempted to supply an analysis of the preconditions of experience and knowledge. In contradistinction, Bartlett's Critique of Impure Reason seeks to provide a critique of the unavoidable limitations of philosophically fundamental concepts that conflict with the preconditions of possible reference, meaning, and knowledge. ${ }^{[16]}$ The latter task is essentially one of identifying, correcting, and eliminating the pervasive variety of conceptual error which it is the book's central purpose to analyze. It is this project which makes the book a critique of "impure reason"- that is, reason that seeks to trespass beyond the limits of possible reference and meaning.

Bartlett makes clear that the Critique of Impure Reason is neither intended as a commentary on Kant, nor as an elaboration of Kant's approach to philosophy. ${ }^{[17]}$ Instead, Bartlett directs attention to a notion, never developed by Kant, but only briefly hinted at by him in a 1770 letter he wrote to Swiss-German philosopher, mathematician, and physicist Johann Heinrich Lambert. In that letter, Kant suggested the need for a "negative science", a "phaenomenologia generalis."[18] To Kant it seemed that such a "negative science" is "presupposed by metaphysics." As Bartlett interprets and develops Kant's briefly sketched notion, ${ }^{[19]}$ a "negative science" would set the general task for itself to avoid conceptual confusions that lead to meaninglessness. ${ }^{[20]}$

Bartlett stresses the need for and the importance of such a "negative science" in philosophy: As Bartlett develops it, negative science serves as a means to differentiate between what is meaningful and what is meaningless: ${ }^{[20]}$ Specifically, its application would identify, correct, and eliminate the widespread form of conceptual error with

12.15.2021). As of this date, the article is well-researched, clearly written, and accurate. I do not take exception to the information currently provided in the entry, although there are some omissions and I would have expressed certain of the book's objectives and claims differently. Reference numbers cited in the Wikipedia article are shown in square brackets; those references appear in this paper in the endnotes section. Hyperlinks in the Wikipedia article that direct internally to other Wikipedia articles have been removed. Like all Wikipedia articles, the text reprinted here is licensed under the Creative Commons Attribution-ShareAlike License. 
which Bartlett is concerned, which he calls "projection" (more technically in the Critique of Impure Reason this is called "metalogical projection"). ${ }^{[21]}$ Such a "negative science" would provide assurance that we employ only concepts, propositions, and statements that do not undermine their very possibility of possessing meaning. Bartlett's Critique of Impure Reason is essentially a treatise that develops such a negative science.

\section{§5. The structure and contents of the Critique of Impure Reason}

\section{The structure of the book}

The thesis of the Critique of Impure Reason: Horizons of Possibility and Meaning is elaborated in three stages:

In the first stage (Part I: Why Philosophy Has Made No Progress and How It Can), Bartlett emphasizes the need for philosophy to evolve to the point where the discipline can supply noncontroversial, determinate, provable solutions to philosophical problems. He supports a rigorously scientific approach to philosophy, one that can establish conclusive results that cannot coherently be evaded or denied. In this first stage of the book, Bartlett identifies a group of psychological blocks or shortcomings found among many philosophers that stand in the way of the discipline's ability to reach indisputable conclusions. For readers not interested in considering the psychological profile characteristic of many philosophers both in the past and today, Bartlett suggests that the first two psychologically-focused chapters of the book can be skipped without loss of the book's main content.

The second principal stage in the book's development contains the technical, substantive core of Bartlett's approach (Part II: The Metalogic of Reference: A New Approach to Deductive, Transcendental Philosophy). Here, Bartlett formulates step-by-step in a series of 13 chapters the methodology that makes it possible to identify, correct, and eliminate the widespread form of conceptual error with which the book is concerned. This central portion of the book formulates a "self-validating" method, one which cannot be rejected without undermining the very possibility of reference and meaning. This part of the book defines an approach to conceptual analysis that makes it possible to recognize the "metalogical horizons" beyond which it is impossible to go without incurring the special variety of "projective" self-referential incoherence which Bartlett was the first to identify, name, and analyze in his 1970 doctoral dissertation. ${ }^{[1]}$

The third main stage of analysis in the Critique of Impure Reason (Part III: Philosophical Applications of the Metalogic of Reference: Major Problems and Questions of Philosophy and the Philosophy of Science) applies the so-called "de-projective method," developed in Part II, to a wide range of major problems of philosophy, including problems of ontology; the problem of the external world; the problem of other minds; the problems of realism and idealism; the problem of time, space, space-time and causality; the problem of the self and of solipsism; as well as others. Part III culminates in three chapters that apply the de-projective method to relativity physics and quantum theory. Bartlett's aim in these latter chapters is to show that the results reached by the Critique of 
Impure Reason confirm or support in a number of important ways many of the same results reached by theoretical physicists in both relativity theory and quantum theory.

The book concludes with Part IV: Horizons, which contains two chapters. The first urges a rigorous, scientific approach in philosophy that goes beyond the mere beliefs that have defined traditional philosophy, and the second summarizes the principal results the long study has reached.

\section{The contents of the Critique of Impure Reason}

The following is an abbreviated table of contents of the Critique of Impure Reason; for conciseness, sections and sub-sections of individual chapters are not listed here:

\section{ABBREVIATED TABLE OF CONTENTS}

Preface

Foreword by Carl Friedrich von Weizsäcker

Acknowledgments

Avant-propos: A philosopher's rallying call

Introduction

A note to the reader

A note on conventions

\section{PART I}

WHY PHILOSOPHY HAS MADE NO PROGRESS AND HOW IT CAN

1 Philosophical-psychological prelude

2 Putting belief in its place: Its psychology and a needed polemic

3 Turning away from the linguistic turn: From theory of reference to metalogic of reference

4 The stepladder to maximum theoretical generality

\section{PART II}

THE METALOGIC OF REFERENCE: A New Approach to Deductive, Transcendental Philosophy

5 Reference, identity, and identification

6 Self-referential argument and the metalogic of reference

7 Possibility theory

8 Presupposition logic, reference, and identification

9 Transcendental argumentation and the metalogic of reference

10 Framework relativity

11 The metalogic of meaning

12 The problem of putative meaning and the logic of meaninglessness

13 Projection

14 Horizons

15 De-projection

16 Self-validation 
17 Rationality: Rules of admissibility

\section{PART III \\ PHILOSOPHICAL APPLICATIONS OF THE METALOGIC OF REFERENCE: Major Problems and Questions of Philosophy and the Philosophy of Science}

18 Ontology and the metalogic of reference

19 Discovery or invention in general problem-solving, mathematics, and physics

20 The conceptually unreachable: "The far side"

21 The projections of the external world, things-in-themselves, other minds, realism, and idealism

22 The projections of time, space, and space-time

23 The projections of causality, determinism, and free will

24 Projections of the self and of solipsism

25 Non-relational, agentless reference and referential fields

26 Relativity physics as seen through the lens of the metalogic of reference

27 Quantum theory as seen through the lens of the metalogic of reference

28 Epistemological lessons learned from and applicable to relativity physics and quantum theory

\section{PART IV:}

HORIZONS

29 Beyond belief

30 Critique of Impure Reason: Its results in retrospect

\section{SUPPLEMENT}

The Formal Structure of the Metalogic of Reference

\section{APPENDIX I}

The Concept of Horizon in the Work of Other Philosophers

\section{APPENDIX II Epistemological Intelligence}

References

Index

About the author

\section{§6. How the Critique of Impure Reason demonstrates or proves its claims}

Central to the book's technique of analysis is Bartlett's "method of de-projection."[22] Briefly stated, the method is designed to bring to light the "metalogical presuppositions" entailed by any frame of reference if that frame of reference is to be capable, in principle, of identifying the class of objects for which the framework is intended. ${ }^{[23]}$ "Metalogical presuppositions" are those that cannot be denied or rejected without undermining the very possibility of reference to that class of objects. This approach to philosophical analysis is 
characterized by Bartlett's original conception and approach to transcendental argumentation, which has a long history, most notably dating back to Kant. In this tradition, and briefly stated, a transcendental argument is one which seeks to demonstrate the necessary "preconditions" without which a thesis or position or claim to knowledge would be rendered impossible. ${ }^{[24]}$

Once the metalogical presuppositions of a frame of reference have been identified, Bartlett's method of de-projection comes into play whenever any concept or claim involves an assertion about a set of objects that they possess an autonomy or are separable from the frame of reference permitting their identification. ${ }^{[25]}$ Such concepts or claims are then recognized as attempted transgressions of the inescapable "metalogical horizon" of that framework of reference. ${ }^{[26]}$ The Critique of Impure Reason claims to demonstrate that such assertions of autonomy or separability are "metalogically projective"- that is, such assertions undermine their own possibility of reference and hence their own possibility of meaning. ${ }^{[27]}$

Throughout the main body of the treatise, this method of analysis is applied in an large variety of philosophical contexts to many of the major problems and questions that have concerned philosophers for centuries. The Critique of Impure Reason seeks to show that a great many major philosophical problems can conclusively be solved in this way.

\section{§7. The philosophical purpose of the Critique of Impure Reason}

The Critique of Impure Reason: Horizons of Possibility and Meaning claims to break new ground in philosophy in the following ways: The book systematically analyzes one major philosophical problem after another, and in each case offers solutions designed to avoid horizon-trespassing, meaningless-entailing attempts to go beyond what can coherently and rationally be thought or expressed. ${ }^{[28]}$ The book then describes how many philosophical problems and the concepts they presuppose can be understood in nonprojective ways that do not lead to self-undermining incoherence ${ }^{[28]}$ In this way, the book proposes a new and revisionary philosophical understanding. ${ }^{[29]}$

In more specific terms, the philosophical purpose of Critique of Impure Reason is made clear by the volume's systematic development in individual chapters of a general theory of possibility (Chapter 7), a broad-spectrum theory of presuppositions (Chapter 8), an inclusive theory of meaning (Chapter 11), and, key to the book's analytical method, a general theory of frameworks and of reference (esp. Chapters 5 and 10).

The book's cover states that the book provides "a revolutionary paradigm shift in philosophical thought." Bartlett explains that such a shift in philosophical thinking comes about once philosophers realize that many of the principal concepts they rely uponconcepts that are presupposed by the major problems which have occupied traditional philosophy - are self-undermining on the level of their possible meaningfulness. If the book is successful in justifying this claim, then the Critique of Impure Reason would be revolutionary for the discipline of philosophy, for then much that has occupied philosophers over millennia would be reinterpreted in a fundamentally revisionary way. 
The book's critique would then be justified in asserting that a great many of the questions of philosophy fall under the heading of impure reason, violating the conditions that must be granted for them to possess possible meaning. ${ }^{[30]}$

The Critique of Impure Reason is a work with a wide philosophical scope, applying a systematically developed method of analysis to many major problems that have engaged philosophers. The treatise of nearly 900 pages and more than 303,000 words is a thoroughgoing work of scholarship with references to more than 600 individual publications, and containing more than 400 explanatory notes.

§8. Recognition of Bartlett's work in philosophy and commendations of the Critique of Impure Reason

Bartlett's work in philosophy has received widespread recognition. In addition to the publication of more than 20 books, edited collections, research monographs, and many papers in professional journals, his research has been funded under grants by the National Science Foundation, the Max-Planck-Gesellschaft, the Alliance Française, the RAND Corporation, the Center for the Study of Democratic Institutions, the American Association for the Advancement of Science, the Lilly Endowment, and others.

The Critique of Impure Reason has received strong commendations from leading philosophers:

- German philosopher and physicist Carl Friedrich von Weizsäcker, former Director of the Max-Planck-Institut in Starnberg, Germany, contributed the book's Foreword, saying of Bartlett's project: "I consider Dr. Bartlett's work soundly conceived and executed with great skill." "[31]

- American philosopher Nicholas Rescher, Distinguished University Professor of Philosophy at the University of Pittsburgh and author of more than 100 books, commends the Critique of Impure Reason's wide scope of study: "I admire its range of philosophical vision." ${ }^{,[32]}$

- German philosopher and sociologist Gerhard Preyer, Professor of Philosophy at Goethe-University, Frankfurt am Main, Germany, the author of many books including Concepts of Meaning, Beyond Semantics and Pragmatics, Intention and Practical Thought, and Contextualism in Philosophy, writes of Bartlett's Critique of Impure Reason: "Bartlett's Critique of Impure Reason is an impressive, bold, and ambitious work. Careful scholarship is balanced by original analyses that lead the reader to recognize the limits of meaning, knowledge, and conceptual possibility. The work addresses a host of traditional philosophical problems, among them the nature of space, time, causality, consciousness, the self, other minds, ontology, free will and determinism, and others. The book culminates in a fascinating and profound new understanding of relativity physics and quantum theory." 
- American philosopher Martin X. Moleski is the author with William Taussig Scott of the only biography of Michael Polanyi to be authorized by Polanyi himself, Michael Polanyi: Scientist and Philosopher, and is a researcher of scientific method, the presuppositions of thought, and the self-referential nature of epistemology. Moleski commends Bartlett's Critique of Impure Reason: "Bartlett has written an American "Prolegomena to All Future Metaphysics." He aims rigorously to eliminate meaningless assertions, reach bedrock, and place philosophy on a firm foundation that will enable it, like science and mathematics, to produce lasting results that generations to come can build on. This is a great book, the fruit of a lifetime of research and reflection, and it deserves serious attention." $"[32]$

- American philosopher and computer scientist Don Perlis, Professor of Computer Science, University of Maryland, and the author of many publications on selfadjusting autonomous systems and philosophical issues involving self-reference, mind, and consciousness, says of Bartlett's Critique of Impure Reason: "Bartlett has written a book on what might be called the underpinnings of philosophy. It has fascinating depth and breadth, and is all the more striking due to its unifying perspective based on the concepts of reference and self-reference.,[32]

\section{§9. Previously published work by Bartlett leading to the Critique of Impure Reason ${ }^{3}$}

In the Critique of Impure Reason Bartlett builds on a series of previous publications by him that span a period of more than 50 years. Publications directly allied to the Critique of Impure Reason include:

- Bartlett's doctoral dissertation A Relativistic Theory of Phenomenological Constitution: A Self-referential, Transcendental Approach to Conceptual Pathology. ${ }^{[1]}$ This work presents within a phenomenological framework a logically compelling method that makes it possible to identify and correct conceptual transgressions that are self-undermining. This is the first work in which Bartlett describes the project of a "critique of impure reason."

- Metalogic of Reference: A Study in the Foundations of Possibility, ${ }^{[3]}$ a monograph that translates Bartlett's earlier phenomenological analysis of conceptual transgressions into the more theoretically neutral terms of what he calls the metalogic of reference.

- A group of papers that apply Bartlett's method to identify, correct, and eliminate such conceptual transgressions; these papers include "The Idea of a Metalogic of Reference,"[4] "Phenomenology of the Implicit,"[5] "Self-reference, Phenomenology, and Philosophy of Science,"[6] "Hoisted by Their Own Petards: Philosophical Positions that Self-Destruct,", Rights: Psychological and Conceptual Blocks,"[8]

\footnotetext{
${ }^{3}$ This section appeared following $\S 3$ in the original Wikipedia article.
} 
- "Referential Consistency as a Criterion of Meaning, ${ }^{[9]}$ which develops and formulates Bartlett's self-validating method of analysis using the tools of mathematical logic. Later revised and elaborated in his Critique of Impure Reason. ${ }^{[10]}$

- Conceptual Therapy: An Introduction to Framework-relative Epistemology ${ }^{[11]}$ an introductory college text describing Bartlett's self-referential approach to conceptual analysis.

- Self-Reference: Reflections on Reflexivity, ${ }^{[12]}$ a collection, edited by Bartlett and Peter Suber with an Introduction by Bartlett, of invited papers that focus on issues and problems involving self-referential argumentation.

- Reflexivity: A Source Book in Self-Reference, ${ }^{[13]}$ a second collection of papers, edited by Bartlett with an Introduction by him, relating to self-reference.

- Two books in the field of clinical psychology which include applications of Bartlett's epistemological approach to conceptual pathology: The Pathology of Man: A Study of Human Evil ${ }^{[14]}$ and Normality Does Not Equal Mental Health: The Need to Look Elsewhere for Standards of Good Psychological Health. ${ }^{[15]}$

§10. External links and resources: Books, monographs, and papers by Steven James Bartlett available online

- A Relativistic Theory of Phenomenological Constitution: A Self-referential, Transcendental Approach to Conceptual Pathology. Doctoral dissertation, Université de Paris, 2 vols., 834 pages: Vol. I in French, and Vol. II in English.

- VALIDITY: A Learning Game Approach to Mathematical Logic. An academic learning game for use in university-level classes in mathematical logic, including both propositional and predicate calculi.

- "Phenomenology of the Implicit". Describes the author's transition from phenomenology to studies of the preconditions of reference.

- "Fenomenologia Tego - Co Implikowane". A Polish translation of the author's "Phenomenology of the Implicit."

- Conceptual Therapy: An Introduction to Framework-relative Epistemology. An introductory college text applying Bartlett's self-validating approach to conceptual analysis.

- Reflexivity: A Source Book in Self-Reference. An edited collection of 33 papers by authors who have contributed to this area of study, including Fitch, Smullyan, Prior, Rescher, van Fraassen, Johnstone, Boyle, Bartlett, and others.

- "Narcissism and Philosophy". This paper examines the personality of many philosophers in terms of psychological narcissism, and argues that, as a result, narcissism characterizes many of the positions that philosophers propound. 
- "Philosophy as Ideology". Examines philosophical positions as exemplifying the defining characteristics of ideology.

- "Psychological Underpinnings of Philosophy". Describes the psychological profile of many philosophers.

- "The Problem of Psychotherapeutic Effectiveness". A paper describing the main determinants of the effectiveness of psychotherapy.

- "Roots of Human Resistance to Animal Rights: Psychological and Conceptual Blocks". A paper examining a variety of blocks that originate in human psychology and in human ways of thinking, blocks that obstruct our recognition of and respect for both the individual consciousness and the legal rights of nonhuman animals.

- "Raízes da resistência humana aos direitos dos animais: Bloqueios psicológicos e conceituais.". A translation into Portuguese of the preceding paper.

- "Wurzeln menschlichen Widerstands gegen Tierrechte: Psychologische und konceptuelle Blockaden." A translation into German of Bartlett's "Roots of Human Resistance to Animal Rights: Psychological and Conceptual Blocks."

- When You Don't Know Where to Turn: A Self-diagnosing Guide to Counseling and Therapy: eBook from Project Gutenberg. Presents an algorithm to aid people in identifying approaches to counseling or therapy likely to be most helpful to them.

- "The Idea of a Metalogic of Reference". An informal introduction to the approach central to Bartlett's epistemology.

- "Referential Consistency as a Criterion of Meaning". In this paper, Bartlett formulates what he calls a "self-validating" criterion of meaning. By this he means a necessary, but not a sufficient, condition of meaning that is logically compelling in the sense that this criterion of meaning cannot not be accepted without bringing about a form of self-referential inconsistency that undermines the very possibility of meaning. Bartlett argues that this "metalogical" variety of self-referential inconsistency comprises a new and distinct kind of self-referential inconsistency, to be distinguished from the philosophically familiar varieties of semantical and pragmatical self-referential inconsistency.

- "The Role of Reflexivity in Understanding Human Understanding". "Introduction" from Steven James Bartlett (Ed.), Reflexivity: A Source-Book in Self-Reference, pp. 3-18.

- The Species Problem: Inescapable Ambiguity and Redundancy. Open access monograph available from ArXiv.org, CogPrints, HAL (Centre pour la Communication Scientifique Directe), and PhilSci. In Bartlett's monograph, the "species problem" refers to past efforts, principally by biologists, to define definitively and objectively what the concept of "species" means. Bartlett seeks to demonstrate two central assertions about the species problem: First, he claims that past efforts to define in any compelling way what "species" means have been unsuccessful because they have failed to understand the theoretical impossibility of the task. It is theoretically impossible, he argues, to define in any compelling 
way what "species" means due to what he calls "the inescapable ambiguity" that is ingredient in the very attempt to reach such a definition. Second, he claims that the solution to the species problem requires what he calls a "framework-relative" approach to species definition. The monograph seeks to demonstrate that such an approach is logically compelling in the sense that it cannot not be accepted without inconsistency.

- "The Case for Government by Artificial Intelligence". A critical and speculative essay, briefly reviewing Bartlett's previous book-length studies relating to shortcomings of psychological normality, and discussing their possible remediation through government by artificial intelligence.

- "Paratheism: A Proof That God Neither Exists nor Does Not Exist". Bartlett argues that theism, atheism, and agnosticism are all fundamentally incoherent from the standpoint of a logical, epistemological analysis. He formulates a proof that theism, atheism, and agnosticism are equally unacceptable because each is "conceptually self-undermining" and therefore incoherent.

- Epistemological Intelligence. An open access monograph available from HAL (Centre pour la Communication Scientifique Directe) and PhilPapers. In this monograph, Bartlett develops the concept of "epistemological intelligence," which he introduces and develops as a new distinguishable variety of human intelligence. He reports his observations of the psychology of philosophers, and claims that the commonly prevailing psychological profile of philosophers often stands in the way of their ability to develop the skills that define epistemological intelligence. A revised version of Epistemological Intelligence appears in Critique of Impure Reason, Appendix II.

- "Mismeasuring Our Lives: The Case against Usefulness, Popularity, and the Desire to Influence Others". In this paper, Bartlett examines what he claims are three important and unquestioned presumptions that fundamentally influence contemporary society, our educational system, and the professions. These presumptions are: the high value that is placed on usefulness, on striving for popularity, and on the wish to influence other people. He presents the case against these presumptions which he claims impede the development of human culture.

- "The Objectivity of Truth, Morality, and Beauty". In this essay, Bartlett advances an innovative approach to answer the perennial question whether truth, morality, and beauty have an objective basis. The essay seeks to show how it is possible to associate three varieties of human intelligence - cognitive intelligence, "moral intelligence," and "aesthetic intelligence"-with justifiable objective judgments about truth, morality, and beauty.

- “America's Upside-down Doctrine of Education: Albert Jay Nock's Theory of What Has Gone Wrong - Or Is It Right?". The American system of education makes important and sometimes unjustified assumptions that were questioned and criticized nearly a hundred years ago by author and educational theorist Albert Jay Nock. This essay discusses Nock's theory of education and finds that certain of the assumptions made by American education stand sorely in need of the support of evidence. 
- "An Insult to the Reader and to Society: Milton's View", reflections on the unproductive constraints imposed by peer review, with a retrospective discussion of John Milton's view. Also available from Cogprints.

- "The Case against the Conventional Publication of Academic and Scientific Books". Bartlett weighs some of the pros and cons of academic and scientific book publishing, and argues on behalf of open access publishing.

- "A Code of Conduct for Peer Reviewers and Editors". In the past few decades, peer review has come to dominate virtually all professionally respectable academic and scientific publications. However, despite its near-universal acceptance, no code of conduct has been developed to which peer reviewers and their editors are encouraged to adhere. This paper proposes such a code of conduct.

\section{§11. Additional online resources}

- A variety of books and papers by Steven James Bartlett; some are abstracted while many others are available in their entirety through PhilPapers and the Social Science Research Network (SSRN).

- Official website (at Willamette University): A selection of Bartlett's downloadable books, papers, and related commentary and discussion.

- Zalta, Edward N. (ed.). "Transcendental Arguments". Stanford Encyclopedia of Philosophy.

- “Transcendental arguments". Internet Encyclopedia of Philosophy.

- Stanford Encyclopedia of Philosophy article Epistemology by Matthias Steup.

- Internet Encyclopedia of Philosophy article "Epistemology". Internet Encyclopedia of Philosophy.

- Encyclopedia Britannica article Epistemology by Avrum Stroll and A.P. Martinich

\section{§12. Postscript: Why this book was published Open Access ${ }^{4}$}

Open Access publishing has many advocated and now-familiar benefits. Open Access publications are made widely, efficiently, and quickly available to readers. Such publications are freed from commercial self-interests: freed from the narrow restrictions of copyright that require, for example, permissions from a publisher and an author if long quotations are desired, and freed from the contractual death grip on a work by publishers whose financial commitments so often supersede and stand in the way of freely releasing a book in order to respond to public, scholarly, and scientific interests. One of the best and most thoughtful works on this subject is Peter Suber's book, Open Access (MIT Press, 2012), itself released the year after its publication on an Open Access basis.

Open Access publishing has a great deal in its favor. However, there are several specific reasons why I have published Critique of Impure Reason on an Open Access basis:

\footnotetext{
${ }^{4}$ This section does not form part of the preceding reprinted Wikipedia article, and like $\S \S 1-2$ is provided under the Creative Commons Attribution-NonCommercial-NoDerivs license. 
In other publications, ${ }^{5}$ I have sought to study the psychology of peer review and editorial bias, and then, with the justification provided, I have criticized their shortcomings. These shortcomings are a direct expression of the five members of the Devil's Quintet: Fashion, Style, Restrictive Paradigms, Preferred Beliefs, and Taste. They are also shortcomings which are the consequence of deeply rooted human predispositions that are encouraged and magnified both by the decision-making power invested in editors, a power which is subject to very little or no accountability, and by the anonymity behind which many peer reviewers may exercise their own individual micromanaging aspirations for power and authority. When the conservative, territorially defending, self-limiting efforts of the Devil's Quintet have their way, buttressed by the very normal psychological predispositions of many editors and peer reviewers, the results of editorial bias and peer review will predictably endorse professional conformity with prevailing fashions, style, restrictive paradigms, preferred beliefs, and tastes.

These results are by no means always bad. They can save scholars and scientists the task - while exempting them from their own responsibility — of separating the wheat from the chaff. They can and do block publication of works unworthy to be published, but in the process they can and do block more than this, sometimes blocking significant original works that go against the prevailing grain. The pre-publication review process is a form of explicit and undisguised censorship. And censorship has a very long history of standing in the way of innovative, original work that conflicts with, or merely discomforts, one or more of the five members of the Quintet.

The Critique of Impure Reason conflicts in some obvious ways with some of the Quintet's preferences today. The book does not conform to certain present-day philosophical preferences - at least certain of the preferences of Anglo-American philosophy. To mention a few examples: The book studies the philosophical topic of

\footnotetext{
5 "The Psychology of Abuse in Publishing: Peer Review and Editorial Bias," which forms Chapter 7 in Steven James Bartlett, Normality Does Not Equal Mental Health: The Need to Look Elsewhere for Standards of Good Psychological Health. Santa Barbara, CA: Praeger, 2011.

"Peer Review-An Insult to the Reader and to Society: Milton's View," reflections on the unproductive constraints imposed by peer review, with a retrospective discussion of Milton's view. Published online June, 2017; available from PhilPapers and from Cogprints.

"Encounters with Intellectual Suppression," an autobiographical essay describing some of the author's experiences with attempted intellectual suppression. Published online Oct., 2017; available from bmartin.cc.

"The Case against the Conventional Publication of Academic and Scientific Books," published online June, 2019. Available from PhilPapers.

"A Code of Conduct for Peer Reviewers and Editors." In the past few decades, peer review has come to dominate virtually all professionally respectable academic and scientific publications. However, despite its near-universal acceptance, no code of conduct has been developed to which peer reviewers and their editors are encouraged to adhere. This paper proposes such a code of conduct. Published online July, 2019. Available from PhilPapers.

Indirectly related to the choices we make in publishing is "Mismeasuring Our Lives: The Case against Usefulness, Popularity, and the Desire to Influence Others," published online Feb., 2018. Available from PhilPapers.
} 
reference, not in terms of today's dominant approach of philosophy of language, but from the standpoint of conceptual analysis. The book furthermore expresses disapproval of philosophy's long history of inconclusive results, and seeks to begin to remedy this. And the book is bold in claiming that some philosophical results can be proved in a manner that cannot be denied without undermining the very basis for rationality. - These are among the book's objectives and claims; some of the members of the Devil's Quintet consider these objectives and claims to be contrary to popular philosophical preferences: they don't comply with the Quintet's requirement of conformity with prevailing standards of philosophical purpose and acceptability. And, in consequence, these objectives and claims were, the author believed, unlikely to elicit an open-armed, unbiased hearing from book editors and peer reviewers.

\section{The cookie-cutter size of commercially published philosophy books}

Look closely at today's catalogs of books published by commercial philosophy publishers. You will find, with few exceptions, that the length of books falls within a cookie-cutter size of not much more than 350 pages. When they go beyond that number of pages, philosophy books tend to be collections of papers or reprinted historical works - whose authors often then wrote longer books.

It would be a difficult challenge today to find a commercial publisher willing to publish a book of the length of the Critique of Impure Reason. If such a publisher were found, the for-profit price of a book of this length would place it out of reach for many individual readers, generally limiting its purchase to university libraries. Bring in the constraints urged by the Devil's Quintet, and the number of willing publishers-for a book that does not bow to mainstream philosophical preferences - predictably becomes quite small.

A book of the length of Kant's Critique of Pure Reason will today, among commercial publishers, be forced to sail against these headwinds. Even to interest philosophy journal editors to review such a long book can be challenging. When the author asked the worldrenowned Review of Metaphysics to consider reviewing the printed edition of Critique of Impure Reason, the editor responded by saying that it would not be possible to find a reviewer willing to read and review such a long book. If published for the first time today, Kant's own Critique of Pure Reason would have a hard time finding willing reviewers. - The cookie-cutter has come to dominate philosophy publishing in multiple ways.

\section{The prejudice in favor of commercial publishers}

Although many academics now recognize the benefits of the freedoms provided by Open Access publishing, conformist/traditionalist biases in favor of printed books - published by peer reviewed commercial presses whose names can bring a certain cachet to the books they publish - still rule when it comes to promotion and tenure. It is largely only senior researchers, who no longer need to collect conventionally endorsed Brownie 
Points on their CVs, who can afford to publish their work free from the constraints of editorial and peer review bias and commercial publishing interests.

To sum up

I chose not to submit the Critique of Impure Reason to any commercial publisher. Instead, I found an independent, non-commercial press willing to publish the long work on an Open Access basis, offering both a free eBook edition and a printed edition sold at cost that can meet the needs of individual readers. As the book's author, my concern has been solely to make the book widely and freely available to readers.

\section{§13. Endnotes}

1. A Relativistic Theory of Phenomenological Constitution: A Self-referential, Transcendental Approach to Conceptual Pathology. 2 vols., 834 pages (Vol. I: French; Vol. II: English). Doctoral dissertation, Université de Paris, 1970. University Microfilms International \#7905583. In 2013, published electronically by Erasmus University Rotterdam in two volumes: Vol. I in French, and Vol. II in English. Each volume contains a terminological index, with tables of contents hyperlinked to the text. Both open access volumes are also available through $\underline{\text { PhilPapers. }}$

2. In the General Introduction to the English edition, Vol. II, §0-11, pp. xx-xxii, and in the Introduction Générale of the French edition (which calls this project "critique de la raison impure”), Vol. I, §0-11, pp. 19-20.

3. Steven James Bartlett, Metalogic of Reference: A Study in the Foundations of Possibility. Starnberg, Germany: Max-Planck-Gesellschaft, 1975.

4. Steven James Bartlett, "The Idea of a Metalogic of Reference." Methodology and Science, Vol. 9, No. 3, 1976, pp. 85-92.

5. Steven James Bartlett, "Phenomenology of the Implicit," Dialectica: Revue international de philosophie de la connaissance, Vol. 29, Nos. 2-3, 1975, pp. 173-188. Published also in Polish translation: "Fenomenologia Tego, Co Implikowane." Roczniki Filozoficzne, Vol. XXII, No. 1, 1974, pp. 73-89.

6. Steven James Bartlett, "Self-Reference, Phenomenology, and Philosophy of Science." Methodology and Science, Vol. 13, No. 3, 1980, pp. 143-167.

7. Steven James Bartlett, "Hoisted by Their Own Petards: Philosophical Positions that Self-Destruct.” Argumentation, Vol. 1, No. 2, 1988, pp. 69-80.

8. Steven James Bartlett, "Roots of Human Resistance to Animal Rights: Psychological and Conceptual Blocks." Animal Law, Vol. 8, 2002, pp. 143-76. Electronically republished 2002 by Michigan State University's Detroit College of Law, Animal Law Web Center. Also translated and published online in German, and then published in Portuguese translation, Steven James Bartlett, "Raízes da resistência humana aos direitos dos animais: Bloqueios psicológicos e conceituais." Brazilian Animal Rights Review (Revista Brasileira de Direito Animal), Vol. 2, No. 3, July/December, 2007, pp. 17-66. Also available online. 
9. Steven James Bartlett, "Referential Consistency as a Criterion of Meaning." Synthese, Vol. 52, 1982, pp. 267-282.

10. In the Critique of Impure Reason especially in Chap. 11 and the book's Supplement, "The Formal Structure of the Metalogic of Reference."

11. Steven James Bartlett, Conceptual Therapy: An Introduction to Framework-relative Epistemology. Saint Louis, MO: Studies in Theory and Behavior, 1983.

12. Steven James Bartlett and Peter Suber (Eds.), Self-Reference: Reflections on Reflexivity. Dordrecht, Holland: Martinus Nijhoff, 1987; now published by Springer Science.

13. Steven James Bartlett (Ed.), Reflexivity: A Source Book in Self-Reference. Amsterdam: Elsevier Science Publishers, 1992. Now published electronically as an open access publication by Erasmus University Rotterdam.

14. Steven James Bartlett, The Pathology of Man: A Study of Human Evil. Springfield, IL: Charles C. Thomas, 2005, in particular Part III, "The Conceptual Pathology of Man."

15. Steven James Bartlett, Normality Does Not Equal Mental Health: The Need to Look Elsewhere for Standards of Good Psychological Health. Santa Barbara, CA: Praeger Publishers, 2011, in particular Chap. 2.

16. Critique of Impure Reason, p. 4.

17. Critique of Impure Reason, p. 5.

18. In his letter, Kant used the misspelling "phaenomologia." Lambert's letter of September 2, 1770, may be found translated into English in Kant, Immanuel (1997). Correspondence. Arnulf Zweig (Trans. \& Ed.). Cambridge: Cambridge Univ. Press, pp. 108-109. (This is an updated and expanded edition of Kant, Philosophical correspondence: 1755-95, Arnulf Zweig (Trans. \& Ed.), Univ. of Chicago Press, 1967 and 1970.)

19. In his letter to Lambert, Kant wrote: "A quite special, though purely negative science, general phenomenology (phaenomologia [sic] generalis), seems to me to be presupposed by metaphysics. In it the principles of sensibility, their validity and their limitations, would be determined, so that these principles could not be confusedly applied to objects of pure reason, as has heretofore almost always happened." Kant, Immanuel (1997). Correspondence. Arnulf Zweig (Trans. \& Ed.). Cambridge: Cambridge Univ. Press, pp. 108-109. See Critique of Impure Reason, pp. 632-636.

20. Critique of Impure Reason, Chap. 29.1.

21. Critique of Impure Reason, Chap. 13.

22. Critique of Impure Reason, Chap. 15.

23. Critique of Impure Reason, Chap. 8, 10, 14, 15.

24. Critique of Impure Reason, Chap. 9.

25. Critique of Impure Reason, Chap. 13.

26. Critique of Impure Reason, Chap. 14.

27. Critique of Impure Reason, Chap. 13-15. 
28. Critique of Impure Reason, Part II.

29. Critique of Impure Reason, Chap. 29 and 30.

30. Critique of Impure Reason, Chap. 30.

31. Critique of Impure Reason, page xxxiv.

32. Critique of Impure Reason, back cover. 